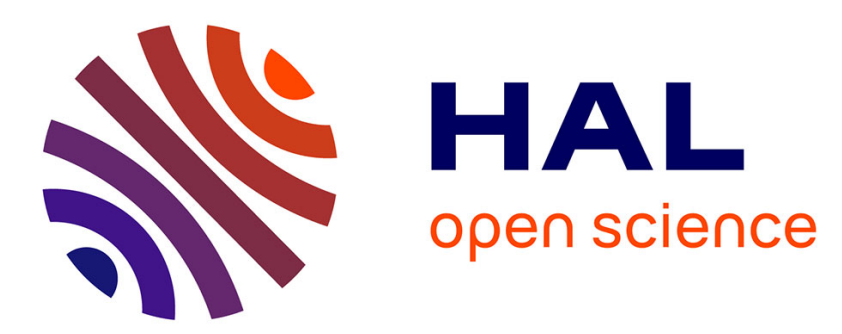

\title{
Feeding patterns of two sympatric shark predators in coastal ecosystems of an oceanic island
}

Clément Trystram, Karyne M Rogers, Marc M Soria, Sébastien Jaquemet

\section{To cite this version:}

Clément Trystram, Karyne M Rogers, Marc M Soria, Sébastien Jaquemet. Feeding patterns of two sympatric shark predators in coastal ecosystems of an oceanic island. Canadian Journal of Fisheries and Aquatic Sciences, 2016, 10.1139/cjfas-2016-0105 . hal-01449339

\section{HAL Id: hal-01449339 \\ https://hal.science/hal-01449339}

Submitted on 30 Jan 2017

HAL is a multi-disciplinary open access archive for the deposit and dissemination of scientific research documents, whether they are published or not. The documents may come from teaching and research institutions in France or abroad, or from public or private research centers.
L'archive ouverte pluridisciplinaire HAL, est destinée au dépôt et à la diffusion de documents scientifiques de niveau recherche, publiés ou non, émanant des établissements d'enseignement et de recherche français ou étrangers, des laboratoires publics ou privés. 


\title{
Feeding patterns of two sympatric shark predators in coastal ecosystems of an oceanic island
}

\author{
Clément Trystram, Karyne M. Rogers, Marc Soria, and Sébastien Jaquemet
}

\begin{abstract}
Stomach contents and stable carbon and nitrogen isotope analyses $\left(\delta^{13} \mathrm{C}\right.$ and $\left.\delta^{15} \mathrm{~N}\right)$ were used to investigate the trophic ecology of two apex predators, tiger sharks (Galeocerdo cuvier) and bull sharks (Carcharhinus leucas), from Reunion Island to describe their dietary habits at both the population and individual levels. In this oceanic island, the tiger and bull sharks were more piscivorous and teutophagous than noted in previous research from other localities. The $\delta^{13} \mathrm{C}$ values suggested that bull sharks depended on more neritic organic matter sources than tiger sharks, confirming a coastal habitat preference for bull sharks. Moreover, the total length of the bull shark influenced $\delta^{13} \mathrm{C}$ values, with smaller individuals being more coastal than larger individuals. All indicators suggest that there is a higher degree of similarity between individual tiger sharks compared with the more heterogeneous bull shark population, which is composed of individuals who specialize on different prey. These results suggest that the two species have different functions in these coastal habitats, and thus, they must be considered independently in terms of conservation and management.
\end{abstract}

Résumé : Les contenus stomacaux et des isotopes stables $\left(\delta^{13} \mathrm{C}\right.$ et $\left.\delta^{15} \mathrm{~N}\right)$ ont été utilisés afin d'étudier l'écologie trophique du requin tigre (Galeocerdo cuvier) et du requin bouledogue (Carcharhinus leucas) à l'île de La Réunion dans le but de décrire leurs habitudes alimentaires aux échelles populationnelle et individuelle. Dans cette étude, les requins tigre et bouledogue sont plus piscivore et plus teutophages que précédemment indiqué dans d'autres endroits. Le $\delta^{13} \mathrm{C}$ suggère que les requins bouledogue dépendent de sources de matière organique plus côtières que les requins tigre, confirmant l'aspect côtier de leur habitat. De plus, le $\delta^{13} \mathrm{C}$ est influencé par la taille des requins bouledogue avec les plus petits individus plus côtiers. Tous les indicateurs suggèrent une plus grande similitude entre les individus de requin tigre comparativement à la population de requins bouledogues composée d'individus hétérogène, chacun étant spécialisé sur différentes proies. Ces résultats montrent que les deux espèces étudiées ont des fonctions différentes dans les habitats côtiers, montrant l'importance de les considérer indépendamment l'une de l'autre en terme de conservation et de gestion.

\section{Introduction}

Understanding the role of large predators in marine ecosystems is important, given that many of these populations are in steep decline, and therefore the critical ecological functions they provide are threatened (Heithaus et al. 2008; Estes et al. 2011). Both empirical and theoretical research supports the belief that large predatory sharks have a key role in marine ecosystem functioning via various processes, such as enhancing ecosystem connectivity due to their high mobility (McCauley et al. 2012) and the top-down pressure they exert on their prey through direct predation (Myers et al. 2007; Baum and Worm 2009; Heupel et al. 2014). Moreover, the presence of predators leads to indirect behavioral effects such as risk avoidance, wherein herbivorous prey become more cautious, thus reducing herbivore intensity, even in the absence of effective predation (Heithaus et al. 2009; Rizzari et al. 2014). However, all of these effects involve a high plasticity of predator ecological niches, resulting in unpredictable consequences of predator loss on ecosystem dynamics and ecological interactions, including stock exploitation by human fisheries (Newman et al. 2006; Myers et al. 2007; Rizzari et al. 2014).

Tiger sharks (Galeocerdo cuvier) and bull sharks (Carcharhinus leucas) are two of the largest marine top-predators. Both species are widespread in tropical and subtropical coastal waters (Compagno 1984).
Bull sharks are one of the few truly euryhaline elasmobranchs and can often be found in freshwater as well as marine environments (Compagno 1984). Although not fully euryhaline, tiger sharks nevertheless also exhibit a high level of tolerance for diverse habitats (Compagno 1984). While principally inhabitants of coastal environments, they are known to undertake large-scale oceanic migrations (Werry et al. 2014; Lea et al. 2015). As such, these species are suitable models to test hypotheses about the physical and biological drivers of ecological niche plasticity.

Historically, the trophic ecology of tiger sharks and bull sharks has been studied mainly via analysis of their stomach contents (e.g., Rancurel and Intes 1982; Werry 2010; Bornatowski et al. 2014) and, more recently, through the use of nonlethal stable isotope techniques (Matich et al. 2011; Daly et al. 2013; Heithaus et al. 2013). Carbon isotopic values $\left(\delta^{13} \mathrm{C}\right)$ vary between organic matter sources (with higher values for benthic algae than for phytoplankton) and habitats (inshore-offshore gradient, with lower values in offshore environments), whereas the nitrogen isotopic value $\left(\delta^{15} \mathrm{~N}\right)$ increases through the food chain (with the relative abundance of ${ }^{15} \mathrm{~N}$ higher in consumers than in prey), providing a tracer of organic matter sources and serving as a proxy for trophic level (Peterson and Fry 1987). As tissue

Received 3 March 2016. Accepted 13 July 2016.

C. Trystram and S. Jaquemet. Université de La Réunion, UMR 9220 ENTROPIE (Université de La Réunion-CNRS-IRD), Avenue René Cassin CS 92003, 97744 Saint-Denis Cedex 9, Ile de La Réunion, France.

K.M. Rogers. National Isotope Centre, GNS Science, P.O. Box 31-312, Lower Hutt, New Zealand.

M. Soria. Institut de Recherche pour le Développement, IRD Réunion, UMR MARBEC (IRD-Ifremer-Univ. Montpellier-CNRS), Parc Technologique Universitaire, 2 rue Joseph Wetzell, 97492 Sainte-Clotilde, Ile de La Réunion, France.

Corresponding author: Clément Trystram (email: clement.trystram@gmail.com).

Copyright remains with the author(s) or their institution(s). Permission for reuse (free in most cases) can be obtained from RightsLink. 


\section{Pagination not final (cite DOI) / Pagination provisoire (citer le DOI)}

turnover requires more time than digestion, stable isotopes represent a longer-term average of dietary habits (turnover rates of muscle and blood are approximately 1 year and 7.5 months, respectively, in large shark species; MacNeil et al. 2006; Logan and Lutcavage 2010; Malpica-Cruz et al. 2012). Although stable isotopes can provide information about long-term dietary habits, they provide much less information about prey taxonomy. Using stable isotope analyses in combination with traditional stomach content analyses forms a robust tool for investigating the trophic ecology of animals (e.g., Fisk et al. 2002; Polo-Silva et al. 2013).

Despite both tiger and bull sharks being widely distributed, only a handful of studies have directly compared their trophic ecologies (Matich et al. 2011), and to our knowledge, no study has made interspecies comparisons of the two sharks in the same location and at the same time. Matich et al. (2011) suggested contrasting patterns of individual specialization between these two species (studied in two distinct areas) that result in different functional roles in marine food webs. The presence of these two species in the waters around Reunion Island provides a unique opportunity to explore the relationships between these two apex predators.

Reunion Island is a young oceanic island of volcanic origin that lies to the east of Madagascar and within the Madagascar regional hotspot of biodiversity. The geomorphology of the island is characterized by the absence of an island shelf, with the exception of the leeward west coast, where it extends up to $5 \mathrm{~km}$ offshore. This isolated system is ideal to study tiger and bull shark ecology at a fine spatial scale.

Stomach contents and two tissue types (blood and muscle) with different turnover rates were analyzed using stable isotopes to ascertain the trophic ecology of these two shark species through the following questions: (1) Are they generalist or specialist foragers at the population level? (2) Is there overlap in their trophic niches? (3) Are their foraging habits dependent on individual length, body condition, capture season, or sex? (4) Do they exhibit trophic specialization at the individual level (i.e., are individuals homogeneous or heterogeneous)?

\section{Methods}

\section{Sample collection and preparation}

Muscle and (or) whole blood and (or) stomach content samples from 31 bull sharks (C. leucas) and 65 tiger sharks (G. cuvier) were collected from individuals caught almost exclusively by local fisherman along the island shelf $\left(\sim 160 \mathrm{~km}^{2}\right.$; Fig. 1) between Saint-Paul and Saint-Gilles on the west coast of Reunion Island between August 2012 and December 2014.

Only individuals older than 2 years of age (i.e., body lengths $>200 \mathrm{~cm}$ for tiger sharks and $>110 \mathrm{~cm}$ for bull sharks; Branstetter and Stiles 1987; Branstetter et al. 1987) were included in the study to negate any artifacts of maternal enrichment influences due to slow muscle turnover rates (Olin et al. 2011). Additional blood samples were collected from live animals during tagging programs (Blaison et al. 2015). All samples were kept in a cool box following collection and thereafter frozen at $-20{ }^{\circ} \mathrm{C}$ in the laboratory until further analysis.

The prey items retrieved from stomachs were counted, weighed to the nearest $0.01 \mathrm{~g}$, identified to the lowest possible taxonomic level using identification keys adapted to taxonomic groups and (or) to anatomical parts (cephalopod beaks, teleost otoliths, and so forth; Clarke 1986; Smith and Heemstra 1986; Smale et al. 1995), and then compared with species lists for the area around Reunion (Letourneur et al. 2004; Durville et al. 2009) and our own reference collection. Paired and unpaired otoliths, beaks, and exoskeleton fragments (cephalothorax and abdomen) were used to assess the number of digested fish, cephalopods, and crustaceans, respectively.

To characterize the trophic habitat of Reunion Island sharks, 36 samples of sedimentary organic matter (SOM) were collected between November 2012 and August 2014 at depths ranging from $10 \mathrm{~m}$ to $100 \mathrm{~m}$ along six inshore-offshore transects. Sixty samples
Fig. 1. Map of the fringing reef and particulate organic matter (POM) and sedimentary organic matter (SOM) sampling sites (solid stars) along Reunion Island's western leeward coast. Inside reef results (open star) were obtained from Kolasinski et al. (2011).

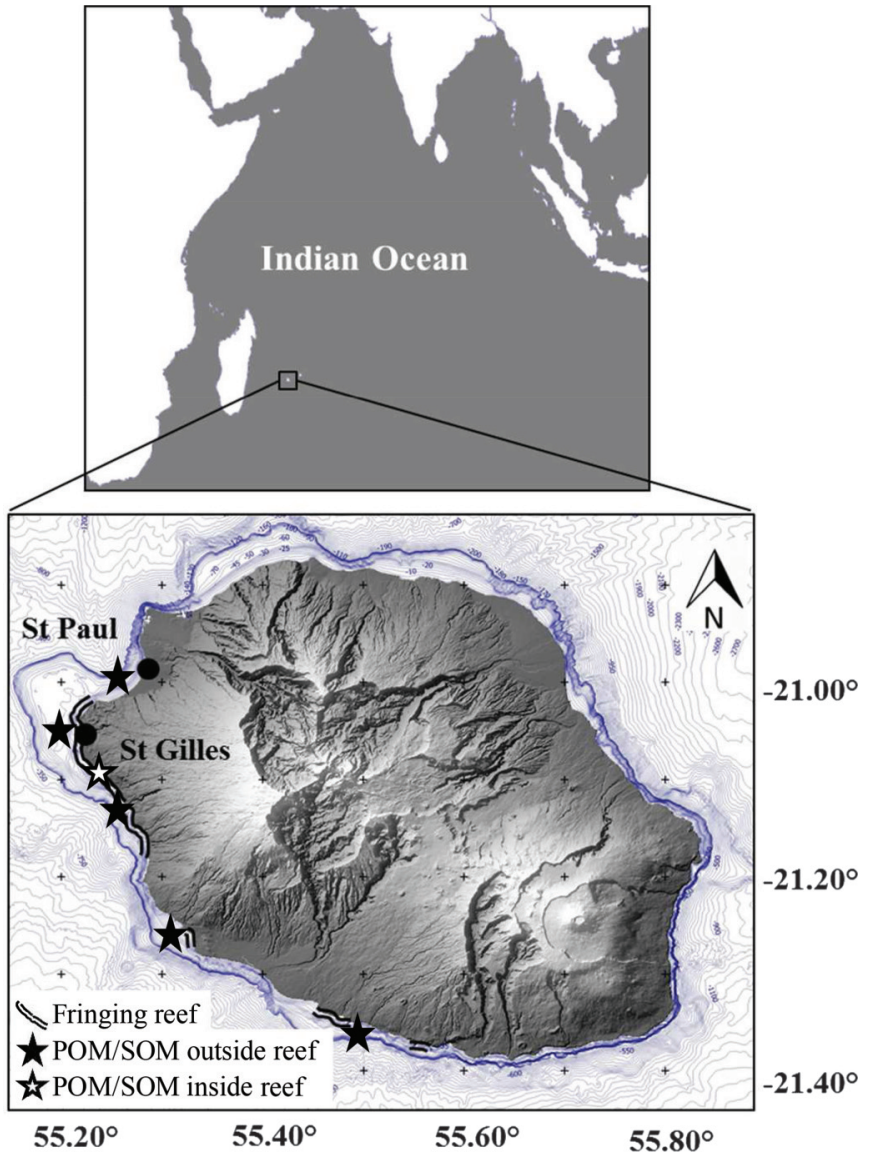

of particulate organic matter (POM) were also collected at the same time. POM samples were obtained by filtering $5 \mathrm{~L}$ of subsurface seawater through precombusted $\left(4 \mathrm{~h}\right.$ at $450{ }^{\circ} \mathrm{C}$ ) Whatman $\mathrm{GF} / \mathrm{F}$ filters (25 mm). Filters were then stored in a cool box and brought back to the laboratory, where they were oven-dried at $50{ }^{\circ} \mathrm{C}$ for $24 \mathrm{~h}$ (Lorrain et al. 2003). Prior to carbon and nitrogen isotope analysis of the organic matter, subsamples of POM and SOM were treated with $1 \mathrm{~mol} \cdot \mathrm{L}^{-1} \mathrm{HCl}$ to remove inorganic carbon (Kolasinski et al. 2011). Published POM and SOM values collected by the same method on the fringing reef of Reunion Island in 2006 and 2007 were used to complement the baseline values of the study area (Kolasinski et al. 2011).

All samples intended for stable isotope analyses, except POM samples, were freeze-dried at $<50 \mathrm{~Pa}$ and $<-40{ }^{\circ} \mathrm{C}$ for $48 \mathrm{~h}$ and then ground into a fine, homogeneous powder using an automated grinder. Approximately $0.5 \mathrm{mg}$ of muscle and blood were weighed and packed into tin capsules. Isotopic composition (with a precision of $0.1 \%$ ofor $\delta^{13} \mathrm{C}$ and $0.1 \%$ for $\delta^{15} \mathrm{~N}$ ) and carbon percentage and nitrogen percentage content were measured at the Stable Isotope Laboratory, GNS Science, Lower Hutt, New Zealand, using an Isoprime isotope ratio mass spectrometer interfaced to an EuroEA elemental analyzer in continuous-flow mode (EA-IRMS). The results were expressed in conventional delta notation ( $\delta)$, according to the following equation (Peterson and Fry 1987):

$$
X=\left[\left(R_{\text {sample }} / R_{\text {standard }}\right)-1\right] 1000
$$

where $R_{\text {sample }}$ and $R_{\text {standard }}$ are the fractions of heavy to light isotopes in the sample and standard, respectively. The $\delta^{13} \mathrm{C}$ and $\delta^{15} \mathrm{~N}$ 


\section{Pagination not final (cite DOI) / Pagination provisoire (citer le DOI)}

isotopes were measured relative to the international standards of Vienna PeeDee Belemnite (VPDB) for carbon and atmospheric air for nitrogen.

Some chemical effects (lipid and urea concentrations) could affect isotopic values, leading several researchers to propose chemical extraction or mathematical correction (Hussey et al. 2012a). However, the higher variability in results and interpretations (Logan and Lutcavage 2010; Hussey et al. 2012a) has led others to recommend that no chemical treatment be applied when the $\mathrm{C} / \mathrm{N}$ ratio (proxy of lipid contents) is low (Post et al. 2007). In our case, the $\mathrm{C} / \mathrm{N}$ ratio was low $(<3.5)$ and constant between tissue types; therefore, no chemical extraction was undertaken (Matich et al. 2011; Vaudo and Heithaus 2011; Malpica-Cruz et al. 2013).

\section{Diet and trophic niche widths}

Prey importance was expressed as the relative numerical abundance (\%N, number of individual prey divided by the total number of consumed prey), relative mass abundance (\%W), and occurrence $(\% \mathrm{O}$, number of stomachs containing the given prey divided by the total number of stomachs, expressed as a percentage). The trophic niche width (TNW) of each population was calculated using the Shannon diversity index (Bolnick et al. 2002):

$$
\mathrm{TNW}=-\sum_{k=1}^{s} p_{k} \ln \left(p_{k}\right)
$$

where $S$ is the number of prey families, and $p$ is the proportional numerical abundance of each prey family $(\% \mathrm{~N})$. This index varies from 0 to $\ln (S)$. The Piélou equitability was then calculated as $\mathrm{TNW} / \ln (S)$, with values varying between 0 (diet dominated by one specific prey type) and 1 (all prey were of equal importance).

Stable isotopes were used to calculate several metrics based on the adaptation of a community index (Layman et al. 2007a) applied at the species scale using each individual as a sampling unit. The mean distance to centroid (CD) provides a measure of the average degree of trophic diversity, which can then be divided into exploited trophic-level diversity $\left(\delta^{15} \mathrm{~N}\right.$ range: NR) and organic matter source diversity $\left(\delta^{13} \mathrm{C}\right.$ range: $\left.\mathrm{CR}\right)$. The mean nearest neighbor distance (MNND) provides a measure of trophic similarity between individuals. Total isotopic niche assessments have previously been determined using the minimum convex hull area (from $\delta^{15} \mathrm{~N}-\delta^{13} \mathrm{C}$ isotopic plots) that contain all individuals, although it is highly biased by outliers (i.e., individuals with extreme positions; Layman et al. 2007b). Kernel-based estimators are robust for small sample sizes and are less sensitive to outliers but are still capable of considering outliers as part of the overall distribution (Fieberg 2007). Analogous to home range, 95\% kernel area was used to assess total isotopic niche (e.g., Franco-Trecu et al. 2014). The 95\% kernel area was generated using the "ks" package of the statistical software R (Duong 2007).

Moreover, the meaningful trophic niche width (i.e., that is likely to be important for a randomly chosen individual) was represented by the standard ellipse corrected for small sample size (SEA $)$, introduced by Jackson et al. (2011) as a bidimensional equivalent of unidimensional mean and variance. Applied SEA ${ }_{c}$ on nonGaussian distribution could lead to misinterpretation because this representation is based on the bivariate normal distribution hypothesis. If required, outliers were removed one by one until an isotopic normal distribution was obtained. SEA $\mathrm{S}_{c}$ is independent from sample size, allowing comparison between species with different sample sizes (Jackson et al. 2011). Except for kernel area, all other isotopic metrics were calculated using "SIAR", a statistical software package using $\mathrm{R}$ (Parnell and Jackson 2011). As isotopic values are expressed in \%o, the kernel area and $S E A_{c}$ are expressed in $\%^{2}$ because these indices represent an area extent on the isotopic biplot.

\section{Evaluation of sampling effort}

Sampling effort was evaluated using cumulative curves generated by plotting cumulative observations (number of prey families or the 95\% isotopic kernel area) against sampling effort (number of preycontaining stomachs or isotopic value). For stomach contents, individual ranking was randomized 100 times to eliminate bias (Cortés 1997). For stable isotopes, bootstrap analyses (100 random selections) were performed to examine the mean 95\% isotopic kernel area across varying sample sizes. Asymptotic curves were then fitted to the observed cumulative prey curves to assess their theoretical diet diversity and breadth (Dengler 2009). To determine if a curve had reached an asymptote, the slope of a linear regression based on the last four endpoints was statistically compared with zero (Bizzarro et al. 2007). If the slope was not zero, the asymptote was not reached, whereas if the slope was zero, the cumulative curve was considered to reach an asymptote.

\section{Niche overlap}

The mean carbon and nitrogen isotope values in muscle and blood samples from both tiger sharks and bull sharks were determined. Differences between species were tested with a Student $t$ test for independent samples for normally distributed data or a Mann-Whitney-Wilcoxon signed rank test for non-normally distributed data. Finally, the area of overlap between the two species' SEA $_{c}$ was calculated to assess the extent of isotopic niche overlap between the two species and obtain an interpretable value similar to previous indices.

Similarities between predator species diets were quantified with Czekanowski index ( $C_{x y}$; Bolnick et al. 2002):

$$
C_{x y}=1-\frac{1}{2} \sum_{i=1}^{S}\left|p_{x i}-p_{y i}\right|
$$

where $S$ is the number of prey families, and $p_{x}$ and $p_{y}$ are the proportional numerical abundances of prey families consumed by species $x$ and $y$, respectively. $C_{x y}$ varies between 0 (complete partition) and 1 (complete overlap). Analogously with Morisita-Horn index, a $C_{x y}$ greater than 0.6 will be considered as significant overlap (Zaret and Rand 1971).

Length, body condition, year, capture season, and sex effect The body condition was determined using a ratio based on a measurement of each individual shark's circumference at the base of the first dorsal fin divided by fork length. The capture season was defined based on Conand et al. (2007) monitoring of sea-surface temperatures (winter: May-October; summer: November-April). The data were tested for normality using a Jarque-Bera test (Thadewald and Büning 2007). The correlation between two quantitative variables (effect of body condition and fork length on carbon and nitrogen isotopic values) was tested using a Pearson or Kendall test depending on normality of the variables. The effects of year, capture season, and sex on carbon and nitrogen isotopic values were tested using Student or Mann-Whitney tests depending on variable normality. All statistical analyses were carried out using R 3.1.2 for Windows with a significant $p$ level set at 0.05 .

\section{Individual specialization}

Isotopic values can be used to determine individual feeding stability over time. When more than one isotopic value per individual is available (e.g., two tissue types), it is possible to separate the total variation into the following two components: the mean sum of square within (MSW) and between (MSB) individuals (Bolnick et al. 2002; Matich et al. 2011). These indices were calculated using the following equations: 


\section{Pagination not final (cite DOI) / Pagination provisoire (citer le DOI)}

$$
\begin{aligned}
& \text { MSW }=\frac{1}{N(K-1)} \sum_{k=1}^{K} \sum_{j=1}^{N}\left(x_{j k}-\bar{x}_{j}\right)^{2} \\
& \text { MSB }=\frac{1}{N-1} \sum_{j=1}^{N}\left(\bar{x}_{j}-\bar{x}\right)^{2}
\end{aligned}
$$

where $N$ is the number of individuals, $K$ is the number of tissues, $x_{j k}$ is the isotopic value $\left(\delta^{13} \mathrm{C}\right.$ or $\left.\delta^{15} \mathrm{~N}\right)$ of tissue $k$ measured on the $j$ th individual, $\bar{x}_{j}$ is the individual isotopic mean, and $\bar{x}$ is the population isotopic mean. Therefore, MSW + MSB represents the total variation, and $\frac{\mathrm{MSW}}{\mathrm{MSW}+\mathrm{MSB}}$ (hereinafter IS) measures the relative degree of individual stability, ranging from 0 (constant diet) to 1 (diet change through time). The calculation was performed using two tissues with high turnover rates: muscle (turnover $\sim 1$ year) and whole blood (turnover $\sim 7.5$ months; Malpica-Cruz et al. 2012), so the assessed stability only covered a short time frame ( $\sim 5$ months).

An adaptation of the Czekanowski index allows a dietary overlap calculation between each individual and the overall population. The mean proportional similarity between individuals and the population (PSI) provided a measure of individual similarity (Bolnick et al. 2002):

$$
\mathrm{PSI}=\frac{1}{N} \sum_{i=1}^{N}\left(1-\frac{1}{2} \sum_{j=1}^{S}\left|p_{i j}-p_{j}\right|\right)
$$

where $N$ is the number of individuals (stomach number), $S$ is the number of prey categories, $p_{i j}$ is the number of $j$ th prey category individuals found in the $i$ th stomach, and $p_{j}$ is the proportion of the $j$ th resource category in the population's niche. Calculated at the individual level, PSI (ranging from 0 , a specialist, to 1 , a generalist) allowed a statistical comparison between $G$. cuvier and C. leucas.

\section{Results}

\section{Dietary composition}

The stomach contents of 24 bull sharks and 58 tiger sharks were analyzed; 16 (67\%) and $30(52 \%)$ stomachs were found to contain prey, respectively. The prey items that were identified to the family level represented 55\% and 70\% of all prey found in bull and tiger shark stomachs, respectively.

The bull sharks we analyzed fed on three major prey groups, representing 13 prey families, with the most common prey consisting of teleosts, represented by 10 identified families, followed by cephalopods and elasmobranchs (Table 1). Indigestible items, such as plastic bags, were found in $25 \%$ of bull shark stomachs.

Tiger sharks consumed a wider variety of prey that consisted of eight major prey categories represented by 22 families. The most common prey items were teleosts and cephalopods, followed by birds. Marine turtles, crustaceans, elasmobranchs, land mammals, and sea stars were also recorded in rare instances (Table 1). Indigestible items, such as plastic bags, hooks, sand, and vegetables were found in $27 \%$ of tiger shark stomachs.

Cumulative curve analyses suggested that $C$. leucas could consume up to 15 prey families and G. cuvier up to 26 prey families, as assessed by asymptote ordinates. The slope of linear regressions performed on the four last points of cumulative curves were significantly different from 0 ( $p<0.05$ in both cases), while being very low ( 0.08 for G. cuvier and 0.07 for C. leucas), demonstrating that the number of $C$. leucas and G. cuvier stomachs included in the analyses were close to the optimal number necessary for describing the diet (Fig. 2A).

Overall, the stomach content compositions of both species varied greatly among individuals, as indicated by the large standard deviations for each parameter compared with the mean values
(Table 2). Thus, the mean number of prey per stomach, the mean mass of the stomach contents, and the mean individual mass of the prey items identified from the stomach contents did not differ significantly between species (Mann-Whitney test, all $p>0.05$; Table 2). The number of prey families found per tiger shark stomach $(2.4 \pm 1.1)$ was significantly higher than those found in bull shark stomachs (1.8 \pm 1.5 , Mann-Whitney test, $p=0.043)$; however, Shannon indices based on numerical abundance (TNW) were quite similar between tiger sharks (2.25) and bull sharks (2.41).

\section{Characterization of organic matter sources}

In the study area, POM $\delta^{13} \mathrm{C}$ values were lower than SOM $\delta^{13} \mathrm{C}$ values (Welch's $t$ test, $p<0.001$ ), whereas POM displayed more similar $\delta^{15} \mathrm{~N}$ values than SOM (Welsh's $t$ test, $p=0.057$; Fig. 3A). Organic matter previously sampled from the fringing reef exhibited more positive $\delta^{13} \mathrm{C}$ values and lower $\delta^{15} \mathrm{~N}$ values than organic matter sampled from outside the reef in this study (Fig. 3A). Thus, the organic matter sources exhibited an overall $\delta^{13} \mathrm{C}$ range of $8.3 \%$ 。 between nearshore waters and deeper waters.

\section{Shark isotopic niche}

Cumulative curve analyses indicated that the maximal isotopic niche (assessed using the kernel approach) for bull sharks would be $4.83 \%^{2}$ for muscle and $3.97 \%^{2}$ for blood, whereas for tiger sharks, the isotopic niche would extend to $5.93 \%{ }^{2}$ for muscle and $6.76 \%{ }^{2}$ for blood. Moreover, these analyses indicated that the numbers of individuals included in this study were not sufficient to describe the isotopic diversity for both species given that their cumulative prey curves did not reach an asymptote (all slopes of linear regressions performed on the four last points were significantly different from $0, p<0.05$ for all test; Fig. 2B). Thus, their isotopic niche sizes appear to be slightly underestimated.

All isotopic niche metrics calculated for both muscle and blood (CR, NR, CD, and 95\% kernel) were found to be larger for tiger sharks than for bull sharks (Table 3), whereas CD did not statistically differ between species or tissues (Kruskal test, $p=0.42$ ). The slightly higher mean trophic diversity (assessed by the mean distance to centroid, CD) of tiger sharks compared with bull sharks could be due to the larger range of values for both carbon isotopes (CR) and nitrogen isotopes (NR). Tiger shark CR represented $63 \%$ of the total range of $\delta^{13} \mathrm{C}$ values for the organic matter sources originating from coral reef and coastal waters, whereas bull shark CR covered $36 \%$ of the $\delta^{13} \mathrm{C}$ value range of organic matter sources (Fig. 3A). The isotopic niche estimates were higher for G. cuvier than for $C$. leucas using both a kernel approach and unbiased standard

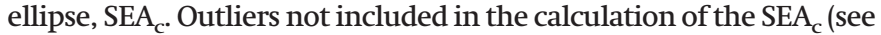
Materials and methods) had more negative $\delta^{13} \mathrm{C}$ values for tiger sharks and less negative $\delta^{13} \mathrm{C}$ values for bull sharks (Figs. 3B and $3 \mathrm{C}$ ). Finally, the tiger shark population was more homogeneous than the bull shark population and exhibited lower MNNDs (Table 3).

\section{Niche overlap}

Bull sharks exhibited carbon isotopic values that were significantly ${ }^{13} \mathrm{C}$-enriched compared with tiger sharks (MannWhitney-Wilcoxon test, $p<0.001$ in both tissues; Table 3). Bull shark muscle was slightly ${ }^{15} \mathrm{~N}$-enriched compared with tiger shark muscle (Student test, $p<0.001$ ), whereas the two species had similar blood $\delta^{15} \mathrm{~N}$ values (Student test, $p=0.06$ ). These differences suggested a niche partitioning between the two species, with no SEA $c$ overlap (Figs. 3B and 3C).

This niche partition is also observed with the Czekanowski dietary overlap index calculated using only the identified prey families found in the stomach contents, which was under the 0.6 threshold $\left(C_{x y}=0.34\right)$.

Length, body condition, year, capture season, and sex effect Tiger sharks sampled in this study were significantly longer than bull sharks (total length $=333 \pm 34 \mathrm{~cm}$ and $268 \pm 39 \mathrm{~cm}$, 
Table 1. Stomach content composition of bull sharks (Carcharhinus leucas) and tiger sharks (Galeocerdo cuvier) caught along the western coast of Reunion Island, expressed in terms of percentage of number $(\% \mathrm{~N})$, mass $(\% \mathrm{~W})$, and occurrence $(\% \mathrm{O})$ of prey categories.

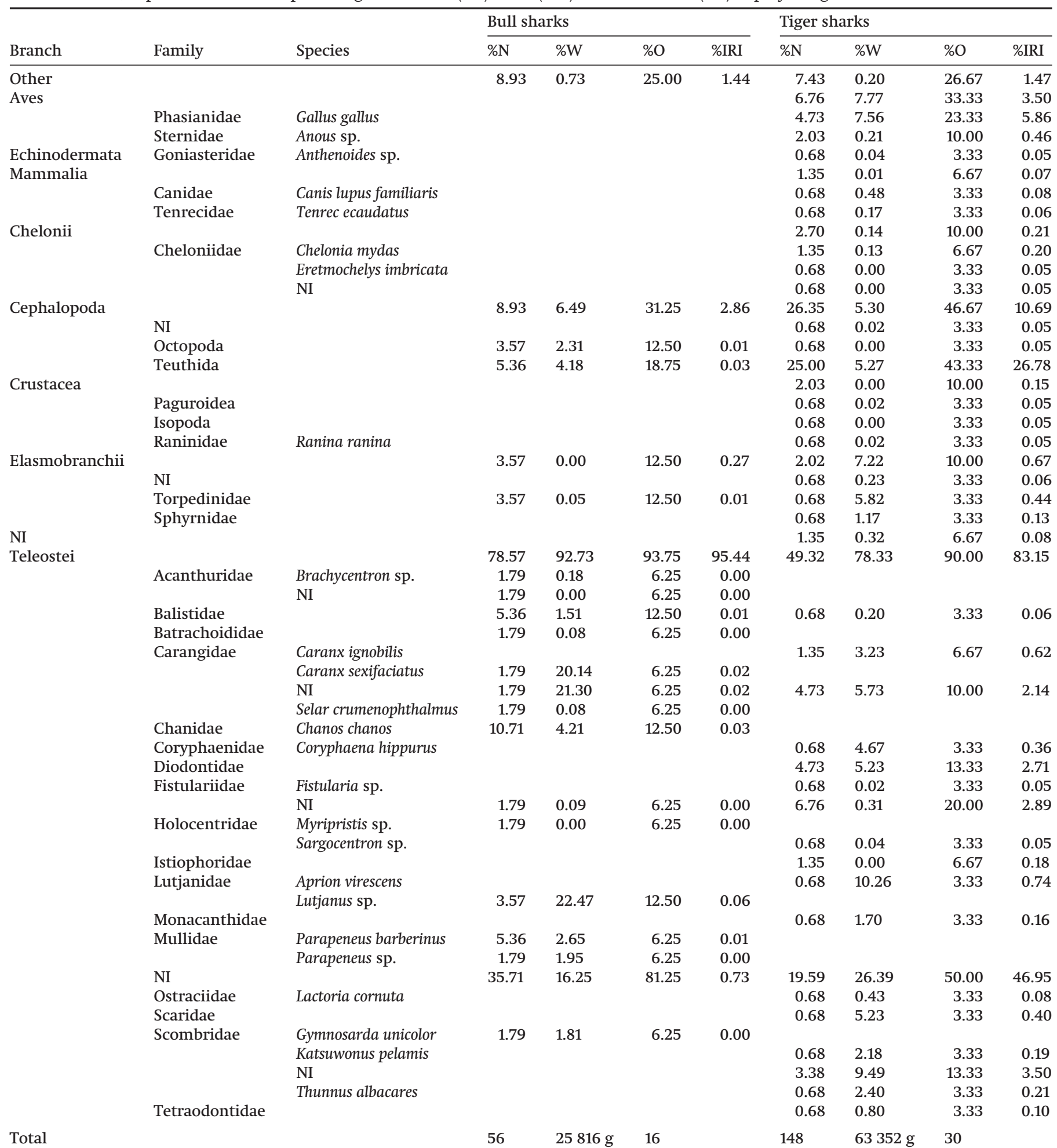

Note: "Total" summarizes the number of prey identified, the cumulative mass of stomach contents, and the number of stomachs containing identifiable prey. $\mathrm{NI}$, not identified; IRI, \%O(\% + \%W), expressed as percentage.

respectively; Mann-Whitney test, $p<0.001$ ). For tiger sharks, carbon and nitrogen stable isotopes measured in muscle and blood showed no fork length, body condition, seasonal, annual, or sex effects (all tests $p>0.05$ ). In contrast, bull shark muscle $\delta^{13} \mathrm{C}$ was affected by fork length $\delta^{13} \mathrm{C}$ (Pearson test, $r=-0.54$; $p=0.002$ ). A seasonal effect was also observed in whole blood $\delta^{13} \mathrm{C}$ (Student test, $p=0.016$ ), switching from $-15.43 \% \circ \pm 0.29 \%$ 。 for individuals caught in the summer to $-14.97 \%$ o $\pm .49 \%$ o for animals caught in the winter. Year, body condition, and sex did not affect $C$. leucas carbon and nitrogen isotopic values (all tests $p>0.05)$. The $\delta^{13} \mathrm{C}$ difference between blood and muscle $\left(\Delta \delta^{13} \mathrm{C}_{\text {blood-muscle }}\right)$ was positively correlated with fork length 


\section{Pagination not final (cite DOI) / Pagination provisoire (citer le DOI)}

Fig. 2. Cumulative prey curves based on (A) stomach contents and (B) stable isotopes. The number of consumed prey families was used as the taxonomic richness. The dashed lines in panel A represent asymptotic model and associated asymptote ordinate.
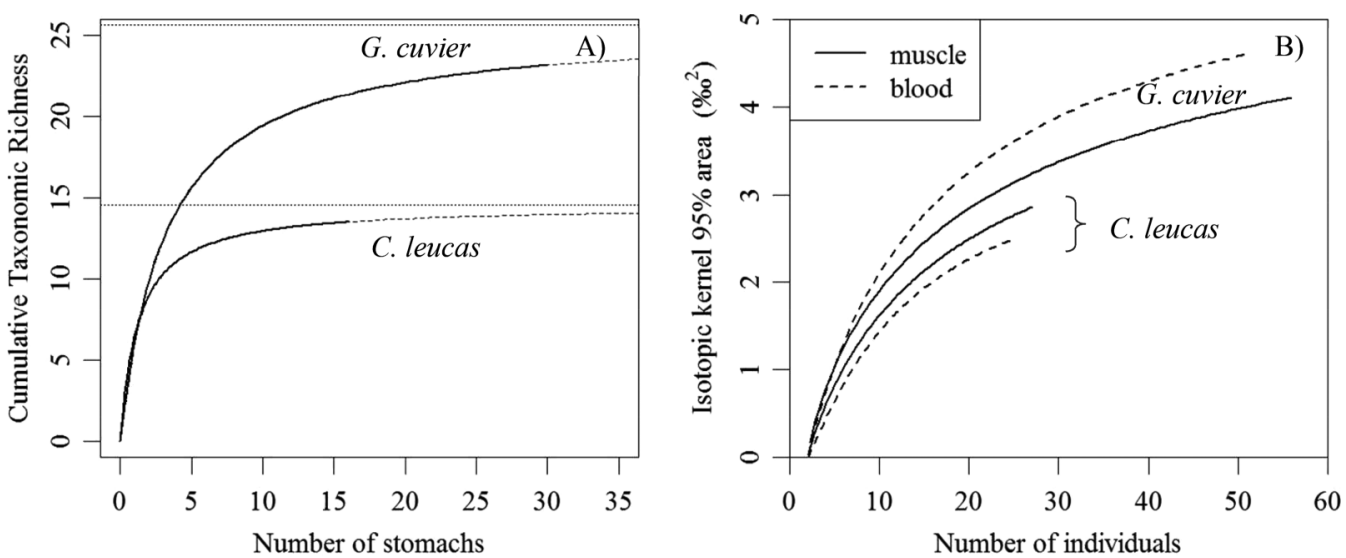

Table 2. Stomach-based trophic niche metrics.

\begin{tabular}{llll}
\hline & C. leucas & G. cuvier & Statistics \\
\hline$N$ stomach & 16 & 30 & \\
$N$ prey & 56 & 148 & \\
Mean TL (min.-max.) & $227.1(178-267)$ & $279.8(206-336)$ & $U=44.5 ; p=0.0001$ \\
Mean prey number per stomach & $3.5 \pm 2.9$ & $4.9 \pm 3.2$ & $U=168 ; p=0.096$ \\
Mean prey mass (g) & $496.5 \pm 1170.4$ & $618.8 \pm 1231.2$ & $U=2949 ; p=0.33$ \\
Mean stomach content mass (g) & $1719.1 \pm 3528.1$ & $2208.3 \pm 2681.4$ & $U=117 ; p=0.17$ \\
Taxonomic richness per stomach & $1.8 \pm 1.5$ & $2.4 \pm 1.1$ & $U=104 ; p=0.043$ \\
Prey family equitability & 0.87 & 0.70 & \\
TNW & 2.41 & 2.25 & \\
PSI & $0.15 \pm 0.13$ & $0.29 \pm 0.18$ & $U=90 ; p=0.02$ \\
\hline
\end{tabular}

Note: The values are given as the mean \pm standard deviation. $N$ stomach, sample size; $N$ prey, number of prey; TL, predator total length; TNW, total niche width; PSI, individual similarity index. Mean taxonomic richness per stomach is expressed in terms of number of prey families.

$(r=0.66 ; p<0.001)$, with longer individuals exhibiting larger intertissue isotopic differences.

\section{Individual specialization}

Individual prey specialization was assessed by comparing carbon and nitrogen isotopes of paired muscle and blood from each of the 22 bull and 49 tiger sharks. Both bull and tiger sharks showed significant isotopic differences between blood and muscle $\left(\Delta \delta^{13} \mathrm{C}_{\text {blood-muscle }}=0.77 \%\right.$ o $\pm 0.24 \%$, Student test, $p<0.001$, $\Delta \delta^{15} \mathrm{~N}_{\text {blood-muscle }}=0.21 \%$ $\pm 0.24 \%$, Student test, $p<0.001$ for bull sharks; $\Delta \delta^{13} C_{\text {blood-muscle }}=0.80 \% \circ \pm 0.40 \%$, Student test, $p<0.001$, $\Delta \delta^{15} \mathrm{~N}_{\text {blood-muscle }}=1.05 \%$ o $\pm .39 \%$, Mann-Whitney test, $p<0.001$ for tiger sharks).

Individual specialization was evaluated using both stable isotopes and stomach contents through the indices IS and PSI, respectively, with higher values indicating greater similarity between individuals. Both methods provided consistent results, with the bull shark population being more heterogeneous than the tiger shark population. Actually, bull shark IS ranged from $14 \%$ (using $\delta^{15} \mathrm{~N}$ values) to $57 \%$ (using $\delta^{13} \mathrm{C}$ values), whereas tiger shark IS ranged from 59\% (using $\delta^{15} \mathrm{~N}$ values) to $38 \%$ (using $\delta^{13} \mathrm{C}$ values). Moreover, bull shark PSI $(0.15 \pm 0.13)$ was significantly lower than tiger shark PSI $(0.29 \pm 0.18)$ (Mann-Whitney test, $U=90, p=0.02$ ).

\section{Discussion}

Although bull sharks and tiger sharks have a long history of interaction with humans (Burgess 2016) and are thought to have important roles in ecosystem functioning (Heithaus et al. 2008), only a handful of studies have explored their foraging ecology to any great extent (a compilation of studies focusing on stomach content analyses is presented in Table 4). The limited amount of research on these species is mainly due to the difficulties of study- ing large and scarce predators, particularly in marine systems. The goal of this study was thus to improve our understanding of the factors influencing trophic niche plasticity. Considering the difficulty to investigate the trophic ecology of these predators, the novelty lies in the use of both stomach content and stable isotope analyses to concomitantly compare two sympatric populations. The description of tiger and bull shark trophic niches was achieved by investigating their pattern of individual specialization. Difficulties related to sampling large, mobile, and scarce animals coupled with their opportunistic feeding behavior led to a lower level of statistic robustness as demonstrated by cumulative curves even though our sample size in this study was comparable to those of previous studies.

\section{Dietary habits at Reunion Island confirms the} opportunistic feeding behaviour of tiger and bull sharks

In this study, both tiger and bull sharks were found to be more piscivorous than previously reported (Table 4). Similarly, the dietary contribution of cephalopods was high for both species (based on stomach content found in $47 \%$ of tiger shark stomachs and $31 \%$ of bull shark stomachs). Such a high proportion of cephalopod consumption by sharks has previously only been reported once, in tiger sharks from South Africa (Smale and Cliff 1998), but cephalopods have never been known to exceed $5.8 \% 0$ of the bull shark diet (Table 4). In contrast with previous studies, turtles, crustaceans, other elasmobranchs, sea snakes, and marine mammals were less abundant or absent in the sharks we analyzed (Table 4). The key difference between the diets of these two species at Reunion Island compared with other localities is likely to be related to the local composition of available prey communities rather than predator selectivity; indeed, both species were considered opportunist because their diets differed regionally. The main prey of tiger sharks have been shown to vary considerably based on location, from te- 


\section{Pagination not final (cite DOI) / Pagination provisoire (citer le DOI)}

Trystram et al.

Fig. 3. Biplot representing individual carbon and nitrogen stable isotope ratios measured in (A) tiger sharks, bull sharks, and organic matter sources. POM and SOM are presented as the mean \pm standard deviation; reef values were obtained from Kolasinski et al. (2011). (B) Shark muscle and $(C)$ shark blood, illustrating the $95 \%$ kernel contour and standard ellipse area (SEA $)$. Outliers were included in the kernel calculation but not in the $S E A_{c}$ representation.
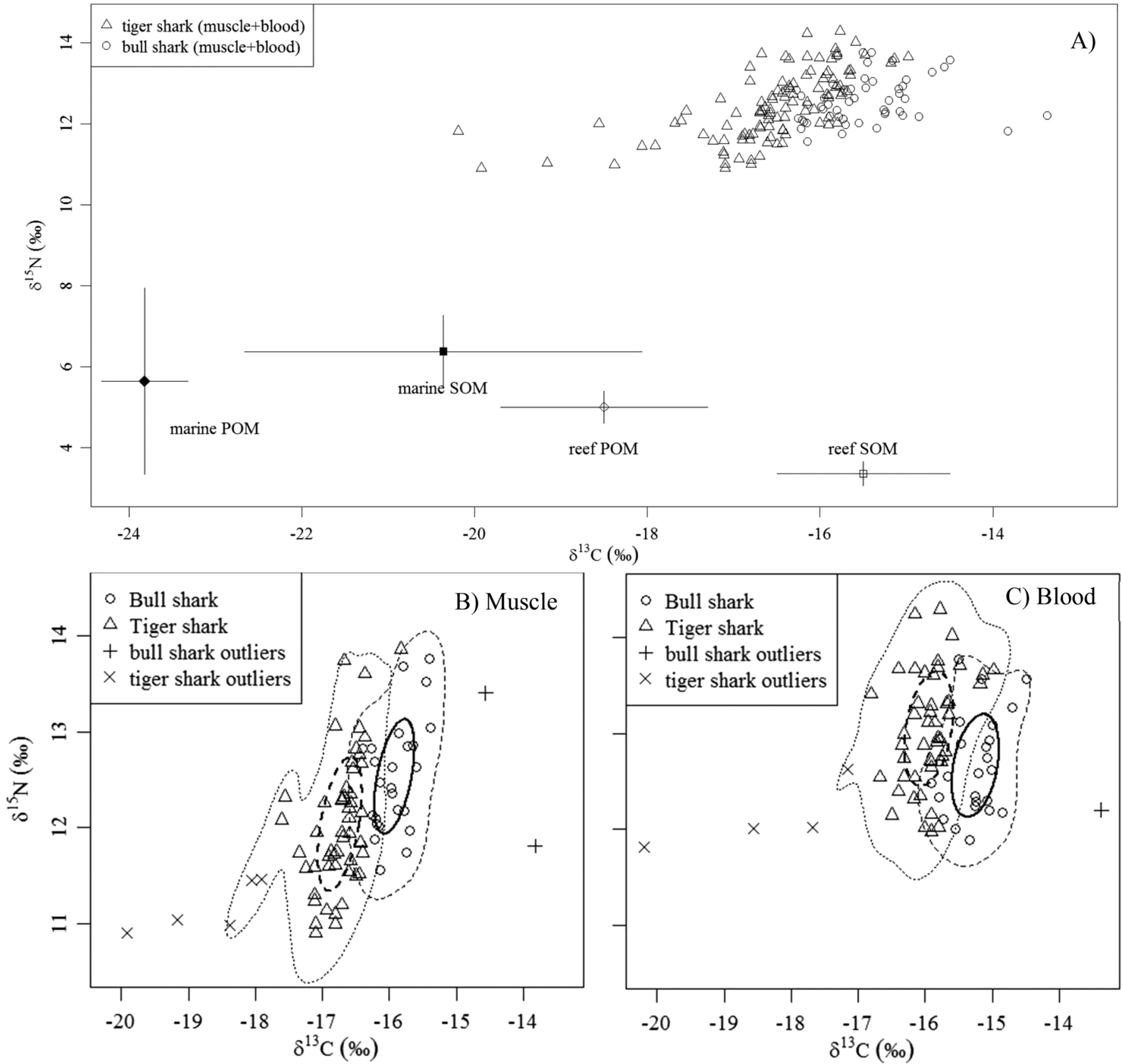

leost fish to sea snakes (in New Caledonia and Eastern Shark Bay), marine turtles (Western Shark Bay), and crustaceans (Northern Hawaiian Island) (Table 4). Interestingly, some tiger sharks have been shown to travel long distances between abovementioned locations (Lowe et al. 2006; Heithaus et al. 2007; Werry et al. 2014), and thus their diets differ between different locations. These large-scale movements between locations highlight the tiger shark's adaptability to local resource availability. Euryhaline bull sharks can switch between freshwater piscivorous diets and estuary- and marine-based diets (Werry 2010) and demonstrate opportunistic foraging strategies, inspecting boats and shore anglers to feed on bait or hooked fish (McCord and Lamberth 2009) or associating with scombrids to feed on anchovy (Pinault and Wickel 2013).
Although the Shannon indices were quite comparable between the two shark species ( 2.25 for tiger sharks and 2.41 for bull sharks), tiger sharks consumed a wider range of prey (22 prey families belonging to eight major prey groups) than bull sharks (13 prey families belonging to three major prey groups). The higher number of prey families consumed by tiger sharks was shown to be independent from sample size (16 versus 30 stomachs containing food for bull and tiger sharks, respectively) because tiger shark's cumulative prey curve was above that for bull sharks for any given sampling effort. Therefore, the number of prey families potentially consumed by bull sharks (estimated at 15 prey families) is predicted to be less than the number of prey families potentially consumed by tiger sharks (estimated at 26 prey families). At the population level, tiger sharks from 


\section{Pagination not final (cite DOI) / Pagination provisoire (citer le DOI)}

Table 3. Metrics quantifying isotopic niche.

\begin{tabular}{|c|c|c|c|c|}
\hline \multirow[b]{2}{*}{ Tissue } & \multicolumn{2}{|c|}{ Tiger shark (G. cuvier) } & \multicolumn{2}{|c|}{ Bull shark (C. leucas) } \\
\hline & Muscle & Blood & Muscle & Blood \\
\hline \multicolumn{5}{|l|}{$N$} \\
\hline Mean fork length (min.-max.; cm) & $333(246-402)$ & $333(246-402)$ & $268(205-325)$ & $272(205-325)$ \\
\hline Mean $\delta^{13} \mathrm{C}(\% \circ)$ & $-16.91 \pm 0.68$ & $-16.13 \pm 0.82$ & $-15.79 \pm 0.55$ & $-15.15 \pm 0.51$ \\
\hline CR (\%) & 4.10 & 5.21 & 2.58 & 2.53 \\
\hline Mean $\delta^{15} \mathrm{~N}(\% \circ)$ & $11.96 \pm 0.71$ & $12.97 \pm 0.62$ & $12.54 \pm 0.60$ & $12.69 \pm 0.57$ \\
\hline NR (\%) & 2.96 & 2.47 & 2.2 & 2.04 \\
\hline $\mathrm{C} / \mathrm{N}$ & $2.90 \pm 0.13 \mathrm{a}$ & $2.84 \pm 0.26 \mathrm{a}$ & $3.02 \pm 0.09 b$ & $2.97 \pm 0.18 \mathrm{~b}$ \\
\hline TA $\left(\%{ }^{2}\right)$ & 5.84 & 6.33 & 3.90 & 3.35 \\
\hline CD (\%) & $0.78 \pm 0.59 a$ & $0.84 \pm 0.72 \mathrm{a}$ & $0.67 \pm 0.44 \mathrm{a}$ & $0.60 \pm 0.42 \mathrm{a}$ \\
\hline MNND \pm SD (\%०) & $0.16 \pm 0.17$ & $0.20 \pm 0.27$ & $0.27 \pm 0.34$ & $0.24 \pm 0.28$ \\
\hline $95 \mathrm{~K}\left(\%{ }^{2}\right)$ & 4.18 & 4.64 & 2.82 & 2.51 \\
\hline $\mathrm{SEA}_{\mathrm{c}}\left(\%{ }^{2}\right)$ & 0.63 & 0.64 & 0.48 & 0.61 \\
\hline
\end{tabular}

Note: $N$, number of samples; CR and $N R$, ranges of $\delta^{13} \mathrm{C}$ and $\delta^{15} \mathrm{~N}$ values, respectively; TA, convex hull area; $\mathrm{CD}$, mean distance to centroid; MNND, mean nearest neighbor distance; $95 \mathrm{~K}, 95 \%$ kernel area; $\mathrm{SEA}_{\mathrm{c}}$, standard ellipse area. Letters indicate statistically significant differences by a Kruskal-Wallis test coupled with MannWhitney multiple comparisons.

Reunion Island would have a larger dietary range than bull sharks in accordance with previous studies (Table 4).

The consumption of a wider range of prey coupled with the fact that $C$. leucas and G. cuvier did not feed on the same fish families (mostly Fistularidae and Diodontidae found in G. cuvier stomachs and Chanidae and Mullidae in C. leucas stomach) led to a clear trophic niche segregation of these two species, as demonstrated by the low overlap index (equal to 0.34 ) well below the 0.6 threshold of a significant overlap.

\section{In limited coastal environments, tiger and bull sharks reduce the competition for resources}

Both stomach contents and stable isotope tiger shark metrics had slightly higher values than bull shark metrics. This observation suggests a higher mobility of tiger sharks than bull sharks and is supported by evidence that tiger sharks undertake largescale offshore migration (Lowe et al. 2006; Heithaus et al. 2007; Werry et al. 2014) while bull sharks seem less mobile (but see Heupel et al. 2015). Tiger sharks appeared to exploit both a greater diversity of organic matter sources and trophic levels. Moreover, bull sharks exhibited higher $\delta^{13} \mathrm{C}$ values in both muscle and blood than tiger sharks. As carbon isotope values vary between pelagic and benthic organic matter sources, carbon isotopic ratios could be considered as a proxy of feeding distance to shore (France 1995; Cresson et al. 2012). The difference in $\delta^{13} \mathrm{C}$ values suggests a segregation of trophic habitats between the two species, with bull sharks depending more on neritic production. This trophic niche partitioning agreed with the higher presence rate of tagged bull sharks $(30 \% \pm 9 \%)$ than tiger sharks $(3.2 \% \pm 0.7 \%)$ tracked by the network of listening stations deployed along the west coast of Reunion Island (Blaison et al. 2015), as well as with published data (coastal-pelagic tiger sharks and coastal, estuarine, and riverine bull sharks; Werry et al. 2011; Lea et al. 2015).

Both populations exhibited ranges of isotope values comparable to the enrichment between a prey and its consumer (i.e., the difference between the individual presenting the lowest values and the individual presenting the highest values was about one trophic level: $\sim 1 \% \circ \delta^{13} \mathrm{C}, \sim 2 \%$ 。 $\delta^{15} \mathrm{~N}$; Hussey et al. 2010; Olin et al. 2013).

However, both tiger and bull sharks analyzed in this particular study presented a narrower isotopic niche width than has been previously found (Matich et al. 2011; Daly et al. 2013; Heithaus et al. 2013); for instance, 18 bull sharks sampled in Mozambique had a $\delta^{13} \mathrm{C}$ range of 6\% (Daly et al. 2013), whereas our study of 27 bull sharks sampled in Reunion Island had a $\delta^{13} \mathrm{C}$ range of only $2.5 \%$. Nevertheless, the extrapolation from the isotopic niche to the trophic niche depends on the isotopic range of food and nutrient sources (Newsome et al. 2007). In fact, the $\delta^{13} \mathrm{C}$ values of both bull sharks and tiger sharks covered $30 \%$ and $63 \%$ of the range of organic matter sources, respectively, demonstrating a high diversity of resource use in the coastal ecosystems of Reunion Island. Thus, the $\delta^{13} \mathrm{C}$ range difference between that found in this study and the scientific literature is probably due to the lower diversity of organic matter sources around Reunion Island compared with the large continental shelves offshore of other locations, such as Mozambique, Australia, and Florida, which experience strong fluvial (containing freshwater and terrestrial) inputs.

\section{Bull sharks do not exhibit the same foraging strategies over} time

At the intraspecific level, bull shark $\delta^{13} \mathrm{C}$ values were influenced by individual fork length (longer individuals had more negative $\delta^{13} C_{\text {muscle }}$ values) and capture season $\left(\delta^{13} C_{\text {blood }}\right.$ values were greater between November and May than between April and October). The seasonal influence on $\delta^{13} \mathrm{C}$ may result either from a baseline seasonal variation or small-scale seasonal movement along the inshoreoffshore gradient or a baseline seasonal variation. The body length effect on $\delta^{13} \mathrm{C}$ suggested that smaller bull sharks derived their energy from resources that depend on coastal primary production, as was found in another empirical study from eastern Australia (Werry et al. 2011). It is important to note, however, that this length effect was detected only in individuals longer than $205 \mathrm{~cm}$ (length at maturity is approximately $204 \mathrm{~cm}$; Cruz-Martínez et al. 2004). Consequently, this result demonstrated that mature individuals are not homogeneous and that foraging shifts occur not only between immature and mature stages but also within the mature stage. Further sampling of juveniles and subadults would be necessary to explore ontogenetic trophic shifts and confirm this trend. The absence of length and seasonal effects on the blood and muscle isotope values for tiger sharks suggests that dietary shifts in this species are limited across adulthood and that individuals exploit the coastal environment of Reunion Island similarly all year round.

\section{Individual specialization is higher in bull sharks compared with tiger sharks}

Tiger and bull shark populations displayed almost identical isotopic niches (assessed by SEA $_{c}$ despite tiger sharks consuming a higher diversity of prey families. The two following hypotheses could explain this finding: (i) a greater isotopic redundancy of tiger shark prey (interpretable in terms of functional redundancy by extrapolation) and (or) (ii) a greater dietary similarity among tiger sharks than among bull sharks. It is not possible to delineate between these hypotheses without sampling prey for stable isotope 


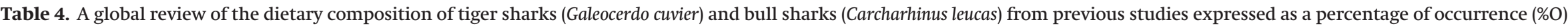
and number $(\% \mathrm{~N})$.

\begin{tabular}{|c|c|c|c|c|c|c|c|c|c|c|c|c|c|c|}
\hline \multirow[b]{2}{*}{ Location } & \multirow[b]{2}{*}{ Indicator } & \multirow[b]{2}{*}{$\mathrm{N}$} & \multicolumn{11}{|c|}{ Prey item } & \multirow[b]{2}{*}{ Reference } \\
\hline & & & Teleosts & Cephalopods & Birds & Elasmobranchs & $\begin{array}{l}\text { Land } \\
\text { mammals }\end{array}$ & Crustaceans & Turtles & Echinoderms & $\begin{array}{l}\text { Sea } \\
\text { snakes }\end{array}$ & $\begin{array}{l}\text { Marine } \\
\text { mammals }\end{array}$ & Gastropods & \\
\hline \multicolumn{15}{|l|}{ Tiger sharks } \\
\hline $\begin{array}{l}\text { Southern } \\
\text { Hawaiian } \\
\text { Islands }\end{array}$ & $\% \mathrm{O}$ & $\mathrm{NS}=198$ & 58 & 13 & 23 & 22 & 19 & 33 & 11 & & & 5 & & Lowe et al. 1996 \\
\hline $\begin{array}{l}\text { Northern } \\
\text { Hawaiian } \\
\text { Islands }\end{array}$ & $\% \mathrm{O}$ & $\mathrm{NS}=57$ & 46.8 & 14.4 & 53.7 & 27.9 & & 64.2 & 26.7 & & & 17.4 & & $\begin{array}{l}\text { Taylor and Naftel, } \\
\text { unpublished data, and } \\
\text { De Crosta et al. 1984, } \\
\text { cited in Lowe et al. } 1996\end{array}$ \\
\hline West Shark Bay & $\% \mathrm{O}$ & $\mathrm{NS}=84$ & 31 & 11 & 14.3 & 10.7 & & 3.6 & 45.2 & & 21.4 & 18.9 & 6 & Simpfendorfer et al. 2001 \\
\hline East Shark Bay & $\% \mathrm{O}$ & $\mathrm{NS}=15$ & 7 & 7 & 7 & 20 & & & 27 & & 60 & 47 & & Heithaus 2001 \\
\hline Queensland & $\% \mathrm{O}$ & $\mathrm{NS}=553$ & 37.2 & 0.4 & 9.3 & & & 10.3 & 9.4 & & 29.3 & & & Simpfendorfer 1992 \\
\hline New Caledonia & $\% \mathrm{O}$ & $\mathrm{NS}=30$ & 21.3 & 6.5 & 43.7 & 4.3 & & 13.0 & 20.0 & & 61.7 & 14.8 & & Rancurel and Intes 1982 \\
\hline Brazil & $\% \mathrm{~N}$ & $\mathrm{NS}=22$ & 75.4 & 2 & 6.1 & 10.1 & & 6.1 & & & & & & Bornatowski et al. 2014 \\
\hline Reunion Island & $\% \mathrm{O}$ & $\mathrm{NS}=30$ & 90 & 47 & 33 & 10 & 6.7 & 10 & 10 & 3.3 & & & & This study \\
\hline \multicolumn{15}{|l|}{ Bull sharks } \\
\hline Florida & $\% \mathrm{~N}$ & $\mathrm{NS}=50 ; \mathrm{NP}=73$ & 71 & & & 19 & & 10 & & & & & & Snelson et al. 1984 \\
\hline Costa Rica & $\% \mathrm{O}$ & $\mathrm{NS}=42$ & 86 & & & 2 & 3 & 10 & 5 & & 2 & & & Tuma 1976 \\
\hline Brazil & $\% \mathrm{~N}$ & $\mathrm{NS}=41 ; \mathrm{NP}=46$ & 89 & & & 11 & & & & & & & & Sadowsky 1971 \\
\hline East Australia & $\% \mathrm{O}$ & $\mathrm{NS}=485$ & 52 & & & 9 & & & 3.4 & & & & & Werry 2010 \\
\hline South Africa & $\% \mathrm{O}$ & - & 71.1 & 5.8 & & 57.5 & & 5.3 & & & & 7.7 & & Olin et al. 2013 \\
\hline South Africa & $\% \mathrm{O}$ & $\mathrm{NS}=309$ & 57.0 & 4.3 & 0.7 & 50.7 & 2.9 & 4.0 & 2.0 & & & 4.3 & 0.5 & Cliff and Dudley 1991 \\
\hline Reunion Island & $\% \mathrm{O}$ & $\mathrm{NS}=16$ & 94 & 31 & & 13 & & & & & & & & This study \\
\hline
\end{tabular}

Note: NS, number of stomachs; NP, number of prey. 


\section{Pagination not final (cite DOI) / Pagination provisoire (citer le DOI)}

analysis, but other clues derived from both stomach contents and stable isotopes indicated that there was a higher degree of similarity in prey items among tiger shark individuals than among bull shark individuals. The feeding niche of bull sharks was more equitably partitioned between individuals who specialized on different prey than that of tiger sharks, as suggested by a lower taxonomic richness per stomach coupled with higher equitability at the population scale. In a theoretical case, if each individual feeds on unique prey, with key differences from one individual to another, then pooling all individuals would result in a good equitability at the population level, with very low taxonomic diversity per stomach. Furthermore, the bull shark mean overlap between each individual and the population average diet (expressed as PSI) was significantly lower than in tiger sharks. This indicated that tiger shark individuals' diet was more similar to each other than diet within bull shark individuals, which were composed of heterogeneous individuals. Isotopically, smaller isotope nearest neighbor distances and a greater ratio of intertissue to interindividual difference (the IS index) also suggested a greater similarity between generalist tiger shark individuals (Bolnick et al. 2002; Layman et al. 2007a). Based on both stable isotopes and stomach contents, the IS based on two high turnover rates tissues (i.e., measuring diet stability between 1 year and several months before catch) to the PSI based on the individual's last meals were consistent.

Dietary resources (in term of species number and biomass) are an important parameter affecting individual specialization; the higher the diversity of resources (number of prey species), the higher the individual predator specialization (Araújo et al. 2011). Moreover, in the case of resource scarcity (low biomass), individuals who specialize on a narrow range of prey demonstrated higher foraging efficiency than those exploiting more diverse resources (Bolnick et al. 2003). In Reunion Island, a high number of species and low biomass compared with other localities in the Indian Ocean (Chabanet et al. 2002, 2016; Pinault et al. 2013) would be expected to promote individual specialization, especially for neritic bull sharks that forage chiefly on coastal fish in these small coastal ecosystems. This pattern of heterogeneous bull sharks and homogeneous tiger sharks in terms of diet has been observed in geographically distinct populations (Florida and Australia, respectively), which could thus be interpreted as being context-dependent (Matich et al. 2011). Our results demonstrated different feeding patterns between two sympatric apex predator populations in a restricted habitat area, suggesting that difference in individual specialization is not only contextdependent but also species-dependent. Further assessment of bull and tiger shark relative abundance in the region is needed to estimate intensity of inter- and intraspecific competition and thus their importance in coastal ecosystems. Moreover, sampling potential prey for stable isotopes would help to both quantify long-term shark diet through mixing models and the trophic environment of the studied shark population.

Caution should be taken when interpreting the results of multitissue stable isotope analyses, as physiological (tissue-specific discrimination factor) and chemical (lipid and urea concentration) effects could lead to intertissue isotopic differences even with a constant diet (Hussey et al. 2012b). Indeed, trophic discrimination factors (i.e., differences between prey and consumer) depend on consumer species, diet quality, and tissue type (Malpica-Cruz et al. 2012; Caut et al. 2013). No controlled feeding experiments have ever been performed on tiger and bull sharks, and published studies on other species do not provide any applicable generalizations (such as correction factors between muscle and blood; Malpica-Cruz et al. 2012; Caut et al. 2013). The trend that emerges from these studies suggests a reduction in $\delta^{13} \mathrm{C}_{\text {blood-muscle }}$ values with treatment, with no effect on nitrogen isotopes, which would exacerbate the observed degree of individual dissimilarity without affecting differences between tiger shark and bull shark populations.

This study was the first to examine the trophic ecology of the sympatric tiger shark and bull shark populations in an isolated oceanic island using both stomach content and multitissue stable isotope analyses. The results of this study demonstrated the clear segregation in the foraging niches of these two apex predators, even for individuals caught in the same area during the same time period, underlining the existence of mechanisms that moderate trophic competition between the two shark species in coastal habitats with limited food resources. This further suggests that the two species have different functions in these coastal habitats and, as such, must be considered independently in terms of conservation and management. Further research on other coastal and oceanic predators (such as giant trevally (Caranx ignobilis) and yellowfin tuna (Thunnus albacares)), prey availability, and relative abundance of tiger and bull sharks in the region would help to better understand their ecological functions.

\section{Acknowledgements}

This study was carried out under the scientific program CHARC (Connaissances de l'écologie et de l'habitat de deux espèces de requins côtiers à La Réunion) with financial support from the Commission of the European Communities (FEDER fund), the French Government, and the Regional Council of Reunion Island. This work was also supported in part by the Western Indian Ocean Marine Science Association (WIOMSA), under a MARG ii Grant (contract 4/2012). The views expressed herein are those of the authors and do not necessarily reflect the views of WIOMSA and Swedish International Development Cooperation Agency. CT was also supported by the Europe Social Fund through a $\mathrm{PhD}$ grant delivered by Regional Council of Reunion Island. The authors are grateful to the fishermen of Reunion Island, A. Blaison, B. Reche (veterinarian), D. Guyomard (Comité Régional des Pêches Maritimes et des Elevages Marins de La Réunion), and the numerous other individuals who participated in sample collection.

\section{References}

Araújo, M.S., Bolnick, D.I., and Layman, C.A. 2011. The ecological causes of individual specialisation. Ecol. Lett. 14(9): 948-958. doi:10.1111/j.1461-0248.2011. 01662.x. PMID:21790933.

Baum, J.K., and Worm, B. 2009. Cascading top-down effects of changing oceanic predator abundances. J. Anim. Ecol. 78(4): 699-714. doi:10.1111/j.1365-2656. 2009.01531.x. PMID:19298616.

Bizzarro, J.J., Robinson, H.J., Rinewalt, C.S., and Ebert, D.A. 2007. Comparative feeding ecology of four sympatric skate species off central California, U.S.A. Environ. Biol. Fishes, 80: 197-220. doi:10.1007/s10641-007-9241-6.

Blaison, A., Jaquemet, S., Guyomard, D., Vangrevelynghe, G., Gazzo, T., Cliff, G., Cotel, P., and Soria, M. 2015. Seasonal variability of bull and tiger shark presence on the west coast of Reunion Island, western Indian Ocean. African J. Mar. Sci. 37(2): 199-208. doi:10.2989/1814232X.2015.1050453.

Bolnick, D.I., Yang, L.H., Fordyce, J.A., and Davis, J.M. 2002. Measuring individual-level resource specialization. Ecology, 83(10): 2936-2941. doi:10. 1890/0012-9658(2002)083[2936:MILRS]2.0.CO;2.

Bolnick, D.I., Svanbäck, R., Fordyce, J.A., Yang, L.H., Davis, J.M., Hulsey, C.D., and Forister, M.L. 2003. The ecology of individuals: incidence and implications of individual specialization. Am. Nat. 161(1): 1-28. doi:10.1086/343878. PMID: 12650459.

Bornatowski, H., Braga, R.R., Abilhoa, V., and Corrêa, M.F.M. 2014. Feeding ecology and trophic comparisons of six shark species in a coastal ecosystem off southern Brazil. J. Fish Biol. 85(2): 246-263. doi:10.1111/jfb.12417. PMID: 24919949.

Branstetter, S., and Stiles, R. 1987. Age and growth estimates of the bull shark, Curcharhinus zeucas, from the northern Gulf of Mexico. Environ. Biol. Fishes, 20(3): 169-181. doi:10.1007/BF00004952.

Branstetter, S., Musick, J.A., and Colvocoresses, J.A. 1987. A comparison of the age and growth of the tiger shark (Galeocerdi cuvieri), from off Virginia and from the northwetsern Gulf of Mexico. Fish. Bull. 85(2): 269-279.

Burgess, G.H. 2016. ISAF statistics on attacking species of shark [online]. Available from https://www.flmnh.ufl.edu/fish/isaf/contributing-factors/speciesimplicated-attacks/.

Caut, S., Jowers, M.J., Michel, L., Lepoint, G., and Fisk, A.T. 2013. Diet- and tissuespecific incorporation of isotopes in the shark Scyliorhinus stellaris, a North Sea mesopredator. Mar. Ecol. Prog. Ser. 492: 185-198. doi:10.3354/meps10478.

Chabanet, P., Bigot, L., Naim, O., Garnier, R., Tessier, E., and Moyne-Picard, M. 2002. Coral reef monitoring at Reunion island (Western Indian Ocean) using the GCRMN method. In Proceedings of the Ninth International Coral Reef Symposium, Bali, 23-27 October 2000. pp. 873-878.

Chabanet, P., Bigot, L., Nicet, J.-B., Durville, P., Massé, L., Mulochau, T., Russo, C., Tessier, E., and Obura, D. 2016. Coral reef monitoring in the Iles Eparses, 
Mozambique Channel (2011-2013). Acta Oecol. 72: 62-71. doi:10.1016/j.actao. 2015.10.010.

Clarke, M.R. 1986. A handbook for the identification of cephalopods' beaks. Clarendon Press, Oxford.

Cliff, G., and Dudley, S.F.J. 1991. Sharks caught in the protective gill nets off Natal, South Africa. 4. The bull shark Carcharhinus leucas Valenciennes. S. Afr. J. Mar. Sci. 10: 253-270. doi:10.2989/02577619109504636.

Compagno, L.J.V. 1984. Sharks of the World. Vol. 4, Part 2, Carcharhiniformes. Fao Species Catalogue. In Food and Agriculture Organisation of the United Nations Fisheries Synopsis, Rome.

Conand, F., Marsac, F., Tessier, E., and Conand, C. 2007. A ten-year period of daily sea surface temperature at a coastal station in Reunion Island, Indian Ocean (July 1993 - April 2004): patterns of variability and biological responses. W. Ind. Ocean J. Mar. Sci. 6(1): 1-16. doi:10.4314/wiojms.v6i1.48222.

Cortés, E. 1997. A critical review of methods of studying fish feeding based on analysis of stomach contents: application to elasmobranch fishes. Can. J. Fish. Aquat. Sci. 54(3): 726-738. doi:10.1139/f96-316.

Cresson, P., Ruitton, S., Fontaine, M.-F., and Harmelin-Vivien, M. 2012. Spatiotemporal variation of suspended and sedimentary organic matter quality in the Bay of Marseilles (NW Mediterranean) assessed by biochemical and isotopic analyses. Mar. Pollut. Bull. 64(6): 1112-1121. doi:10.1016/j.marpolbul.2012. 04.003. PMID:22541382.

Cruz-Martínez, A., Chiappa-Carrara, X., and Arenas-Fuentes, V. 2004. Age and growth of the Bull Shark, Carcharhinus leucas, from southern Gulf of Mexico. J. Northw. Atl. Fish. Sci. 35: 367-374. doi:10.2960/J.v35.m481.

Daly, R., Froneman, P.W., and Smale, M.J. 2013. Comparative feeding ecology of bull sharks (Carcharhinus leucas) in the coastal waters of the southwest Indian Ocean inferred from stable isotope analysis. PLoS ONE, 8(10): e78229. doi:10. 1371/journal.pone.0078229. PMID:24205168.

Dengler, J. 2009. Which function describes the species-area relationship best? A review and empirical evaluation. J. Biogeogr. 36: 728-744. doi:10.1111/j.13652699.2008.02038.x.

Duong, T. 2007. ks: Kernel density estimation and kernel discriminant analysis for multivariate data in R. J. Stat. Softw. 21(7): 1-16. doi:10.18637/jss.v021.i07.

Durville, P., Mulochau, T., Barrere, A., Quod, J., Quero, J., and Ribes, S. 2009. Inventaire des poissons récoltés lors de l'éruption volcanique d'avril $2007 \mathrm{du}$ piton de la Fournaise (île de La Réunion). Ann. la société des Sci. Nat. 9(9): 948-956.

Estes, J.A., Terborgh, J., Brashares, J.S., Power, M.E., Berger, J., Bond, W.J., Carpenter, S.R., Essington, T.E., Holt, R.D., Jackson, J.B.C., Marquis, R.J., Oksanen, L., Oksanen, T., Paine, R.T., Pikitch, E.K., Ripple, W.J., Sandin, S.A., Scheffer, M., Schoener, T.W., Shurin, J.B., Sinclair, A.R.E., Soulé, M.E., Virtanen, R., and Wardle, D.A. 2011. Trophic downgrading of planet Earth. Science, 333: 301-306. doi:10.1126/science.1205106. PMID:21764740.

Fieberg, J. 2007. Kernel density estimators of home range: smoothing and the autocorrelation red herring. Ecology, 88(4): 1059-1066. doi:10.1890/06-0930. PMID:17536721.

Fisk, A.T., Tittlemier, S.A., Pranschke, J.L., and Norstrom, R.J. 2002. Using anthropogenic contaminants and stable isotopes to assess the feeding ecology of greenland sharks. Ecology, 83(8): 2162-2172. doi:10.1890/0012-9658 (2002)083[2162:UACASI]2.0.CO;2.

France, R.L. 1995. Carbon-13 enrichment in benthic compared to planktonic algae: foodweb implications. Mar. Ecol. Prog. Ser. 124: 307-312. doi:10.3354/ meps124307.

Franco-Trecu, V., Aurioles-Gamboa, D., and Inchausti, P. 2014. Individual trophic specialisation and niche segregation explain the contrasting population trends of two sympatric otariids. Mar. Biol. 161(3): 609-618. doi:10.1007/s00227013-2363-9.

Heithaus, M.R. 2001. The biology of tiger sharks, Galeocerdo cuvier, in Shark Bay, Western Australia: sex ratio, size distribution, diet, and seasonal changes in catch rates. Environ. Biol. Fishes, 61: 25-36. doi:10.1023/A:1011021210685.

Heithaus, M.R., Wirsing, A.J., Dill, L.M., and Heithaus, L.I. 2007. Long-term movements of tiger sharks satellite-tagged in Shark Bay, Western Australia. Mar. Biol. 151(4): 1455-1461. doi:10.1007/s00227-006-0583-y.

Heithaus, M.R., Frid, A., Wirsing, A.J., and Worm, B. 2008. Predicting ecological consequences of marine top predator declines. Trends Ecol. Evol. 23(4): 202210. doi:10.1016/j.tree.2008.01.003. PMID:18308421.

Heithaus, M.R., Wirsing, A.J., Burkholder, D., Thomson, J., and Dill, L.M. 2009. Towards a predictive framework for predator risk effects: the interaction of landscape features and prey escape tactics. J. Anim. Ecol. 78(3): 556-562. doi:10.1111/j.1365-2656.2008.01512.x. PMID:19076259.

Heithaus, M., Vaudo, J., Kreicker, S., Layman, C., Krützen, M., Burkholder, D., Gastrich, K., Bessey, C., Sarabia, R., Cameron, K., Wirsing, A., Thomson, J., and Dunphy-Daly, M. 2013. Apparent resource partitioning and trophic structure of large-bodied marine predators in a relatively pristine seagrass ecosystem. Mar. Ecol. Prog. Ser. 481: 225-237. doi:10.3354/meps10235.

Heupel, M., Knip, D., Simpfendorfer, C., and Dulvy, N. 2014. Sizing up the ecological role of sharks as predators. Mar. Ecol. Prog. Ser. 495: 291-298. doi:10. 3354/meps10597.

Heupel, M.R., Simpfendorfer, C.A., Espinoza, M., Smoothey, A.F., Tobin, A., and Peddemors, V. 2015. Conservation challenges of sharks with continental scale migrations. Front. Mar. Sci. 2: 1-7. doi:10.3389/fmars.2015.00012.

Hussey, N.E., Brush, J., McCarthy, I.D., and Fisk, A.T. 2010. $\delta^{15} \mathrm{~N}$ and $\delta^{13} \mathrm{C}$ diet- tissue discrimination factors for large sharks under semi-controlled conditions. Comp. Biochem. Physiol. A. Mol. Integr. Physiol. 155(4): 445-453. doi: 10.1016/j.cbpa.2009.09.023. PMID:19800980.

Hussey, N.E., MacNeil, M.A., Olin, J.A., McMeans, B.C., Kinney, M.J., Chapman, D.D., and Fisk, A.T. 2012a. Stable isotopes and elasmobranchs: tissue types, methods, applications and assumptions. J. Fish Biol. 80(5): 14491484. doi:10.1111/j.1095-8649.2012.03251.x. PMID:22497393.

Hussey, N.E., Olin, J.A., Kinney, M.J., McMeans, B.C., and Fisk, A.T. 2012b. Lipid extraction effects on stable isotope values $\left(\delta^{13} \mathrm{C}\right.$ and $\left.\delta^{15} \mathrm{~N}\right)$ of elasmobranch muscle tissue. J. Exp. Mar. Biol. Ecol. 434-435: 7-15. doi:10.1016/j.jembe.2012. 07.012..

Jackson, A.L., Inger, R., Parnell, A.C., and Bearhop, S. 2011. Comparing isotopic niche widths among and within communities: SIBER - Stable Isotope Bayesian Ellipses in R. J. Anim. Ecol. 80(3): 595-602. doi:10.1111/j.1365-2656.2011. 01806.x. PMID:21401589.

Kolasinski, J., Rogers, K., Cuet, P., Barry, B., and Frouin, P. 2011. Sources of particulate organic matter at the ecosystem scale: A stable isotope and trace element study in a tropical coral reef. Mar. Ecol. Prog. Ser. 443: 77-93. doi: 10.3354/meps09416.

Layman, C.A., Arrington, D.A., Montaña, C.G., and Post, D.M. 2007a. Can stable isotope ratios provide for community-wide measures of trophic structure? Ecology, 88(1): 42-48. doi:10.1890/0012-9658(2007)88[42:CSIRPF]2. 0.CO;2. PMID:17489452.

Layman, C.A., Quattrochi, J.P., Peyer, C.M., and Allgeier, J.E. 2007b. Niche width collapse in a resilient top predator following ecosystem fragmentation. Ecol. Lett. 10(10): 937-944. doi:10.1111/j.1461-0248.2007.01087.x. PMID:17845294.

Lea, J.S.E., Wetherbee, B.M., Queiroz, N., Burnie, N., Aming, C., Sousa, L.L., Mucientes, G.R., Humphries, N.E., Harvey, G.M., Sims, D.W., and Shivji, M.S. 2015. Repeated, long-distance migrations by a philopatric predator targeting highly contrasting ecosystems. Sci. Rep. 5: 1-11. doi:10.1038/srep11202.

Letourneur, Y., Chabanet, P., Durville, P., Taquet, M., Teissier, E., Parmentier, M., Quéro, J., and Pothin, K. 2004. An updated checklist of the marine fish fauna of Reuin Island, South-Western Indian Ocean. Cybium, 28(3): 199-216.

Logan, J.M., and Lutcavage, M.E. 2010. Stable isotope dynamics in elasmobranch fishes. Hydrobiologia, 644(1): 231-244. doi:10.1007/s10750-010-0120-3.

Lorrain, A., Savoye, N., Chauvaud, L., Paulet, Y.-M., and Naulet, N. 2003. Decarbonation and preservation method for the analysis of organic $\mathrm{C}$ and $\mathrm{N}$ contents and stable isotope ratios of low-carbonated suspended particulate material. Anal. Chim. Acta, 491: 125-133. doi:10.1016/S0003-2670(03)00815-8.

Lowe, C.G., Wetherbee, B.M., Crow, G.L., and Tester, A.L. 1996. Ontogenic dietary shifts and feeding behavior of the tiger shark, Galeocerdo cuvier, in Hawaiian waters. Environ. Biol. Fishes, 47: 203-211. doi:10.1007/BF00005044.

Lowe, C.G., Wetherbee, B.M., and Meyer, C.G. 2006. Using acoustic telemetry monitoring techniques to quantify movement patterns and site fidelity of sharks and giant trevally around French Frigate shoals and Midway atoll. Atoll Res. Bull. 543: 281-303.

MacNeil, M.A., Drouillard, K.G., and Fisk, A.T. 2006. Variable uptake and elimination of stable nitrogen isotopes between tissues in fish. Can. J. Fish. Aquat. Sci. 63(2): 345-353. doi:10.1139/f05-219.

Malpica-Cruz, L., Herzka, S.Z., Sosa-Nishizaki, O., and Lazo, J.P. 2012. Tissuespecific isotope trophic discrimination factors and turnover rates in a marine elasmobranch: empirical and modeling results. Can. J. Fish. Aquat. Sci. 69(3): 551-564. doi:10.1139/f2011-172.

Malpica-Cruz, L., Herzka, S.Z., Sosa-Nishizaki, O., and Escobedo-Olvera, M.A. 2013. Tissue-specific stable isotope ratios of shortfin mako (Isurus oxyrinchus) and white (Carcharodon carcharias) sharks as indicators of size-based differences in foraging habitat and trophic level. Fish. Oceanogr. 22(6): 429-445. doi:10.1111/fog.12034.

Matich, P., Heithaus, M.R., and Layman, C.A. 2011. Contrasting patterns of individual specialization and trophic coupling in two marine apex predators. J. Anim. Ecol. 80(1): 294-305. doi:10.1111/j.1365-2656.2010.01753.x. PMID:20831730.

McCauley, D.J., Young, H.S., Dunbar, R.B., Estes, J.A., Semmens, B.X., and Micheli, F. 2012. Assessing the effects of large mobile predators on ecosystem connectivity. Ecol. Appl. 22(6): 1711-1717. doi:10.1890/11-1653.1. PMID:23092009.

McCord, M., and Lamberth, S. 2009. Catching and tracking the world's largest Zambezi (bull) shark Carcharhinus leucas in the Breede Estuary, South Africa: the first 43 hours. Afr. J. Mar. Sci. 31(1): 107-111. doi:10.2989/AJMS.2009.31.1. 11.782 .

Myers, R.A., Baum, J.K., Shepherd, T.D., Powers, S.P., and Peterson, C.H. 2007. Cascading effects of the loss of apex predatory sharks from a coastal ocean. Science, 315(5820): 1846-1850. doi:10.1126/science.1138657. PMID:17395829.

Newman, M.J.H., Paredes, G.A., Sala, E., and Jackson, J.B.C. 2006. Structure of Caribbean coral reef communities across a large gradient of fish biomass. Ecol. Lett. 9: 1216-1227. doi:10.1111/j.1461-0248.2006.00976.x. PMID:17040324.

Newsome, S.D., Martinez del Rio, C., Bearhop, S., and Philips, D.L. 2007. A niche for isotopic ecology. Front. Ecol. Environ. 5(8): 429-436. doi:10.1890/ 060150.01.

Olin, J.A., Hussey, N.E., Fritts, M., Heupel, M.R., Simpfendorfer, C.A., Poulakis, G.R., and Fisk, A.T. 2011. Maternal meddling in neonatal sharks: implications for interpreting stable isotopes in young animals. Rapid Commun. Mass Spectrom. 25(8): 1008-1016. doi:10.1002/rcm.4946. PMID:21452377.

Olin, J.A., Hussey, N.E., Grgicak-Mannion, A., Fritts, M.W., Wintner, S.P., and Fisk, A.T. 2013. Variable $\delta^{15} \mathrm{~N}$ diet-tissue discrimination factors among sharks: 


\section{Pagination not final (cite DOI) / Pagination provisoire (citer le DOI)}

implications for trophic position, diet and food web models. PLoS ONE, 8(10): e77567. doi:10.1371/journal.pone.0077567.

Parnell, A.A., and Jackson, A. 2011. SIAR: Stable isotope analysis in R. R Package, version 4.1.3.

Peterson, B.J., and Fry, B. 1987. Stable isotopes in ecosystem studies. Annu. Rev. Ecol. Syst. 18: 293-320. doi:10.1146/annurev.es.18.110187.001453.

Pinault, M., and Wickel, J. 2013. What appears to be a defensive behavior in the anchovy could also be a double-edged sword. Coral Reefs, 33(2): 343-343. doi:10.1007/s00338-013-1116-z.

Pinault, M., Chabanet, P., Loiseau, N., Durville, P., Galzin, R., and Quod, J. 2013. Influence des facteurs environnementaux sur la structure des peuplements ichtyologiques de l'île de La Réunion (Sud-Ouest de l'océan Indien). Cybium, 37(3): 95-109.

Polo-Silva, C., Newsome, S.D., Galva, F., Grijalba-bendeck, M., and Sanjuan-mun, A. 2013. Trophic shift in the diet of the pelagic thresher shark based on stomach contents and stable isotope analyses. Mar. Biol. Res. 9(10): 958-971. doi:10.1080/17451000.2013.793802.

Post, D.M., Layman, C.A., Arrington, D.A., Takimoto, G., Quattrochi, J., and Montaña, C.G. 2007. Getting to the fat of the matter: models, methods and assumptions for dealing with lipids in stable isotope analyses. Oecologia, 152(1): 179-189. doi:10.1007/s00442-006-0630-x. PMID:17225157.

Rancurel, P., and Intes, A. 1982. Le requin tigre, Galeocerdo cuvier, Lacépède des eaux Néocalédoniennes examen des contenus stomacaux. Tethys, 10: 195199.

Rizzari, J.R., Frisch, A.J., Hoey, A.S., and McCormick, M.I. 2014. Not worth the risk: apex predators suppress herbivory on coral reefs. Oikos, 123: 829-836. doi:10.1111/oik.01318.

Sadowsky, V. 1971. Notes on the bull shark Carcharhinus leucas in the lagoon region of Cananeia, Brazil. Bol. do Inst. Oceanogr. 20(2): 71-78.

Simpfendorfer, C.A. 1992. Biology of Tiger Sharks (Galeocerdo cuvier) caught by the Queensland Shark Meshing Program off Townsville, Australia. Aust. J. Mar. Freshw. Res. 43(1): 33-43. doi:10.1071/MF9920033.

Simpfendorfer, C.A., Goodreid, A.B., and McAuley, R.B. 2001. Size, sex and geographic variation in the diet of the tiger shark, Galeocerdo cuvier, from
Western Australian waters. Environ. Biol. Fishes, 61: 37-46. doi:10.1023/A: 1011021710183.

Smale, M.J., and Cliff, G. 1998. Cephalopods in the diets of four shark species (Galeocerdo cuvier, Sphyrna lewini, S. zygaena and S. mokarran) from KwazuluNatal, South Africa. S. Afr. J. Mar. Sci. 20: 241-253. doi:10.2989/025776 198784126610.

Smale, M.J., Watson, G., and Hecht, T. 1995. Otolith atlas of southern African marine fishes. Smith Institute of Ichthyology, Grahamstown.

Smith, M.M., and Heemstra, P.C. 1986. Smith's sea fishes. Springer-Verlag.

Snelson, F.F., Mulligan, T.J., and Williams, S.E. 1984. Food habits, occurence, and population structure of bull shark, Carcharhinus leucas, in Florida coastal lagoons. Bull. Mar. Sci. 34(1): 71-80.

Thadewald, T., and Büning, H. 2007. Jarque-Bera test and its competitors for testing normality: a power comparison. J. Appl. Stat. 34(1): 87-105. doi:10.1080/ 02664760600994539 .

Tuma, R.E. 1976. An investigation of the feeding habits of the bull shark, Carcharhinus leucas, in the Lake Nicaragua - Rio San Juan System. Investig. Ichthyofauna Nicar. Lakes: 39.

Vaudo, J., and Heithaus, M. 2011. Dietary niche overlap in a nearshore elasmobranch mesopredator community. Mar. Ecol. Prog. Ser. 425: 247-260. doi:10. 3354/meps08988.

Werry, J.M. 2010. Habitat ecology of the bull shark, Carcharhinus leucas, on urban coasts in eastern Queensland, Australia. Griffith University Gold Coast.

Werry, J.M., Lee, S.Y., Otway, N.M., Hu, Y., and Sumpton, W. 2011. A multi-faceted approach for quantifying the estuarine-nearshore transition in the life cycle of the bull shark, Carcharhinus leucas. Mar. Freshw. Res. 62(12): 1421-1431. doi:10.1071/MF11136.

Werry, J.M., Planes, S., Berumen, M.L., Lee, K.A., Braun, C.D., and Clua, E. 2014. Reef-fidelity and migration of tiger sharks, Galeocerdo cuvier, across the Coral Sea. PLoS ONE, 9(1): e83249. doi:10.1371/journal.pone.0083249. PMID: 24421879.

Zaret, T.M., and Rand, A.S. 1971. Competition in tropical stream fishes: support for the Competitive Exclusion Principle. Ecology, 52(2): 336-342. doi:10.2307| 1934593. 